\title{
The Performance of REIT Acquirers in the Post-Merger Period
}

\section{Chris Ratcliffe}

\section{Bill Dimovski}

\section{Monica Keneley}

\section{Executive Summary}

Mergers and acquisitions are a feature of modern economies. However, research on conventional bidding firms in mergers and acquisitions (M\&As) has shown, on average, shareholders are worse off in the long-run (Alexandridis, Mavrovitis and Travlos, 2012). This study examines the long-term post merger performance of US Equity Real Estate Investment Trusts (REITs) to see if this underperformance extends to the largest REIT sector in the world. In contrast to the earlier REIT data samples used by Campbell, Giambona and Sirmans (2009), we find, prior to the macroeconomic event of the financial crisis, that existing shareholders of bidding firms earn significant and positive abnormal returns. This outcome supports the synergy motive for M\&As in the REIT sector. Results from announcements occurring after the onset of the financial crisis show signs of negative and significant abnormal returns, suggesting these M\&As were driven by the agency and/or hubris motive.

Keywords REITs, Equity REITs, Mergers and Acquisitions, Post-merger abnormal returns

JEL Classifications G11; G14; G34 


\section{INTRODUCTION}

Mergers and acquisitions are an ongoing process as markets respond to internal and external pressures. A key issue arising from this activity is the extent to which it promotes efficient market outcomes. From an economic perspective, mergers and acquisitions (M\&As) should provide for the efficient management of companies, improved mobility of capital and an efficient allocation of scarce resources (Manne, 1965). However, there is growing evidence of underperformance of bidding firms shares in the years following the M\&A announcement (Alexandridis, Mavrovitis and Travlos, 2012, Bessembinder and Zhang, 2013). Jensen and Ruback (1983, p.20) comment 'these post-outcome negative abnormal returns are unsettling because they are inconsistent with market efficiency and suggest that changes in stock prices overestimate the future efficient gains from mergers'. Such arguments are supported by Campbell, Giambona and Sirmans (2009) who argue that these types of results are troubling as they suggest the existence of weak form market efficiency. The ensuing informational problems translate into an inefficient allocation of resources.

Whilst the debate surrounding the issue of post merger performance continues, one issue that has received less attention is that of the motivations of acquiring firms. If acquiring firms do not reap the returns expected, why do they engage in such activities? Berkovitch and Narayanan (1993) identify several motives for M\&As; namely the synergy motive, the hubris hypothesis and the agency motive. The post-announcement under-performance of acquirers suggests that the motivation for M\&As may be a result of hubris and/or agency issues rather than efficiency considerations (Alexandridis, Mavrovitis and Travlos, 2012, Ang, Yingmei and Nagel, 2008, Conn, Cosh, Guest and Hughes, 2005). If the M\&A is motivated by hubris and/or manager's self-interest, this may result in negative abnormal post-announcement performance (Ratcliffe, Dimovski and Keneley, 2015). Savor and Lu (2009) argue that manager's views may be influenced by prior performance and therefore overpay for an acquisition. If this were the case, then it would add support to the hypothesis that weak form market efficiency exists. To test this line of argument the current study explores the performance of the American Real Estate Investment (REIT) market.

The American REIT sector comprises a significant component of the US financial market. The 223 REITS listed on the FTSE in December 2015 had a market capitalisation of \$US939 billion (https://www.reit.com/data-research/data/industry-snapshot accessed 28/1/2016). Globally these 
institutions represent 63.9\% of the international REIT market (European Public Real Estate Association). Within the REIT sector, Equity REITs make up the majority of entities and accounted for 94\% of market capitalisation of all US REITs (that also includes mortgage REITs) in 2015. Given the size of this market and its contribution to the American economy, analysis of the outcomes of M\&As in this market can provide insights into broader performance issues that accompany industry consolidation. The purpose of this paper is twofold. First, to investigate if under-performance extends to the US REIT sector, in particular Equity REITs. Second to examine the motivation(s) of REIT M\&As in the post-announcement period. Anderson, Medla, Rottke and Schiereck (2012) argue that the findings of previous studies are inconclusive and leave many questions unanswered. The current study aims to provide further insight into the drivers of M\&A decisions.

This paper extends the body of research that has pointed to conflicting performance outcomes postM\&As by Sahin (2005) and Campbell, Giambona and Sirmans (2009). It also considers the impact of market disruption and regulatory change on post-performance results. It utilizes a later dataset that captures the impact of both the introduction of the REIT Modernization Act of 1999 and the global financial crisis. The Act paved way for REITs to own up to $100 \%$ of a taxable REIT subsidiary and included a reduction in the mandatory payout requirement to $90 \%$ of earnings (Howe and Jain, 2004). Howe and Jain (2004) argue that the changes in the regulatory environment as a result of the Act transformed REITs, impacting on their growth, risk and profitability. If such is the case, it could be expected that performance outcomes may have altered. The under performance issues noted in earlier studies may not be as apparent with the change in the market environment.

We examine 63 Equity REIT M\&A announcements from 2000 to 2014 over the one, two and threeyear event windows. To assess the post-announcement performance of bidders two methodologies are employed. The first is the buy-and-hold abnormal returns (BHAR) method, described by Barber and Lyon (1997). The second is based on the Fama and French (1993) three-factor model. As Gregory (1997) and Limmack (1997) have pointed out, the choice of event study methodology to assess longterm performance can have an important impact on the level of excess returns. Utilizing two different methods will enable the study to test the robustness of the post-announcement performance of bidders.

Prior US REIT research by Campbell, Giambona and Sirmans (2009) and Sahin (2005) has produced mixed results. Sahin (2005) examined REIT acquisitions from 1994 to 1998 and observed a positive 
and significant median BHAR over the three-year event window. While Campbell, Giambona and Sirmans (2009) detected BHARs over the five-year period to be negative and significant during their study period of 1994 to 2001. Our findings for the full Equity REIT sample from January 2000 to September 2014 suggest that the REIT M\&A market is informationally efficient. We find no significant negative abnormal performance post announcement. Moreover, when the sample was separated to take into account the financial crisis we find support for the synergy motive in the prefinancial crisis period. Both BHARs and three-factor model abnormal returns are indeed positive and significant. Post-crisis results show signs of negative abnormal returns, suggesting such synergy motivations had altered It is hypothesised that this result is due to the high volatility and uncertainty in the sector during the crisis, making it difficult for bidders to integrate the assets of the targets and achieve synergistic benefits.

The remainder of this paper proceeds as follows. The literature section reviews the relevant literature in this area providing the context to the present study. Next we describe the data collection process and methodologies employed. The results and discussions are then presented and finally we provide our concluding comments.

\section{LITERATURE REVIEW}

This review examines the prior literature in respect to the motivation and performance of REITs following a M\&A announcement. The three major motives for M\&As collated previously by Berkovitch and Narayanan (1993) provide a useful start. The synergy motive suggests that M\&As result in the realisation of economic gains with the merging of the resources of two firms, leading to positive wealth effects for the acquiring firms shareholders (Sudarsanam, Holl and Salami, 1996). The hubris hypothesis argues management make mistakes in evaluating targets and engage in M\&As even where there is no synergy (Roll, 1986). If positive gains are observed around announcement it may be that the result is due to true synergies (Roll 1986). However, management may still make errors in valuation resulting in a decline in bidding firm value following the M\&A announcement (Dodd, 1980, Kiymaz and Baker, 2008). The agency motive suggests M\&As occur because managers pursue their own self-interest, sometimes at the expense of shareholders (Jensen, 1986, Malatesta, 1983, Morck, Shleifer and Vishny, 1990). 
Agrawal and Jaffe (2000) provide an extensive review of the post-acquisition literature from 1974 to 1998. The majority of early studies employed either a market model or market adjusted model to calculate the cumulative average abnormal returns (CARs). Results of these early studies show evidence of the hubris and/or agency motive, with acquirers earning negative abnormal returns postannouncement. For example, Ellert (1976), Dodd and Ruback (1977) and Malatesta (1983) all found negative CARs over the post announcement period utilising the market model.

Langetieg (1978) pointed to the possible disadvantages of these early methodologies employed in estimating post merger performance. ${ }^{1}$ The author estimated acquirer excess by calculating the difference between the bidding firm's performance and the performance of a non-bidding control portfolio. Results showed that acquiring firms earn insignificant abnormal returns over the one and two-year timeframes. Langetieg (1978) concluded that the control firm approach results are consistent with the efficient market hypothesis.

\section{Buy-and-Hold Abnormal Returns}

Kothari and Warner (1997), Barber and Lyon (1997) and Lyon, Barber and Tsai (1999) have criticised the methodologies employed in the early post-announcement studies and recommend the use of a buyand-hold methodology. Kothari and Warner (1997) argue that the market model approach does not account for possible shifts in the parameters used to calculate expected returns. In addition, Barber and Lyon (1997) contend that the shift in the parameters impacts on excess returns and the variances used to estimate the test statistics. Early results employing BHAR methodology, returned insignificant excess returns over the three-year post announcement period (Higson and Elliott, 1998, Mitchell and Stafford, 2000).

Subsequent studies however, observed significant negative BHARs post-M\&A announcement. In the UK, Cosh and Guest (2001), Sudarsanam and Mahate (2003) and Conn, Cosh, Guest and Hughes (2005) observed negative and significant BHARs over the three to four-year post announcement period, ranging from $-7.50 \%$ to $-16.30 \%$. Betton, Eckbo and Thorburn (2007) examined US M\&As and found significant negative BHARs of $-21.90 \%$ over the five-year post-announcement period. Ang, Yingmei and Nagel (2008) also observed negative and significant BHARs of $-5.02 \%$. Following on from these US studies, Bouwman, Fuller and Nain (2009) detected negative and significant BHARs of 
-7.22\%. Finally, Bessembinder and Zhang (2013) found acquirers earn negative and significant BHARs of $-7.90 \%$ over the five-year post announcement period.

\section{Fama-French Three-Factor Model}

Fama and French (1993) propose that the three-factor asset-pricing model be employed to examine long-term abnormal performance because the returns can be described by the size and book-to-market factors. Mitchell and Stafford (2000, p.288) argue 'the systematic errors that arise with imperfect expected return proxies - the bad model problem - are compounded with long-horizon returns'. Mitchell and Stafford (2000) also argue that the BHAR method ignores any cross-sectional dependence of the over-lapping excess returns of individual event firms.

Gregory (1997) examined UK M\&As utilising the three-factor model. Results showed bidders earn negative and significant mean monthly abnormal returns (ARs) of $-0.75 \%$. This result was supported by later studies examining US acquirers (Gaspar, Massa and Matos, 2005, Mitchell and Stafford, 2000) and Canadian M\&As (André, Kooli and L'Her, 2004). All three studies report negative and significant mean monthly ARs ranging from $-0.20 \%$ to $-0.75 \%$.

However, Moeller, Schlingemann and Stulz (2004), observed insignificant non-negative monthly ARs. Similarly, Croci, Petmezas and Vagenas-Nanos (2010) study of UK M\&As from 1990 to 2005 also reported insignificant mean monthly ARs. Subsequent studies employing the three-factor model display mixed results. For example, Bouwman, Fuller and Nain (2009), Dutta and Jog (2009) and Latorre, Herrero and Farinós (2014) all observed positive and significant mean monthly ARs, ranging from $+0.52 \%$ to $+0.70 \%$, in their studies of the US, Canadian and Spanish M\&A markets respectively. In contrast, Alexandridis, Antoniou and Zhao (2006) report significant negative excess returns of 1.02\% in their UK study and Alexandridis, Mavrovitis and Travlos (2012) finds US bidders earn negative and significant mean ARs of $-0.25 \%$.

A number of researchers have adopted mixed methodologies to test the robustness of their results. These studies have employed both the BHAR and three-factor methods. Conn, Cosh, Guest and Hughes (2005) observed negative and significant post-announcement performance across both methods. ${ }^{2}$ While Croci, Petmezas and Vagenas-Nanos (2010) and Datta, Kodwani and Viney (2013) detected insignificant excess returns in both methodologies. Dutta and Jog (2009) present positive and significant ARs from the three-factor model, but insignificant positive BHARs. Finally, Bouwman, 
Fuller and Nain (2009) produced completely contrasting results. Three-factor average monthly ARs were $+0.66 \%$ and significant (equating to a cumulative average AR of $+15.84 \%$ over the two-year event period), compared to a negative and significant BHAR of $-7.22 \%$. Unfortunately, the authors did not provide an explanation for the contrasting results. They did, however, cite Loughran and Ritter (2000) who state that 'since different methods have different powers of detecting abnormal performance, there should be differences in abnormal return estimates across different methodologies' (Bouwman, Fuller and Nain, 2009, p.654). This study acknowledges this and therefore employs both methods to provide robustness to the results.

\section{REIT Post-announcement Performance}

Research into REIT post announcement shareholder performance has been limited to three papers. Two of these investigated the US REIT market (Campbell, Giambona and Sirmans, 2009, Sahin, 2005) and the other examined the Australian REIT (A-REIT) sector (Ratcliffe, Dimovski and Keneley, 2015). Sahin (2005) investigated the long-term performance of acquiring REITs utilising both the BHAR and three-factor model methods over the three-year post announcement period. The study examined 30 REIT M\&As from 1994 to 1998 . BHARs results over the three-year event window were $+3.56 \%$, however the result was not significant. The median BHAR was significant at the $10 \%$ level and positive (+11.62\%). These outcomes provide support for the synergy motive for REIT M\&As. In contrast, three-factor model results showed acquirers earn mean monthly ARs of $-0.50 \%$, however, the result lacked statistical significance. ${ }^{3}$

Following on from Sahin (2005), Campbell, Giambona and Sirmans (2009) conducted the second investigation into the long-term wealth effects of M\&As within the REIT sector. The study consisted of 85 equity REIT M\&A announcements between 1994 and 2001. The study observed negative and significant BHARs of $-9.9 \%$ over the five-year post acquisition period. The study also calculated BHARs of $+0.3 \%$ for the 12 month period and $-1.5 \%$ for 36 months, however neither result displayed statistical significance. Campbell, Giambona and Sirmans (2009) concluded that the results confirm that post-acquisition underperformance of REITs is consistent with those observed in more general corporate finance studies and provide support for the hubris and/or agency motive.

Ratcliffe, Dimovski and Keneley (2015) examined 65 A-REIT M\&A announcements from 1996 to 2012. The study employed both BHAR and three-factor methodologies. ${ }^{4}$ Results showed that bidders 
earn negative and significant abnormal returns across both models. The two and three-year postannouncement BHARs were $-8.21 \%$ and $-12.27 \%$ respectively and the two-year three-factor model observed a CAR of $-12 \%$. The results are consistent with Campbell, Giambona and Sirmans (2009) and further support the hubris and/or agency motive for REIT M\&As.

However, Ratcliffe, Dimovski and Keneley (2015) identified a structural break in the data set due to the financial crisis. After partitioning the results, the authors observed that the negative excess returns for the full sample were being driven by the financial crisis. Pre-crisis BHAR and three-factor excess returns were positive and significant. While long-term excess returns extended across the financial crisis were negative and highly significant. Ratcliffe, Dimovski and Keneley (2015) concluded that acquirers may have unwittingly over-paid for the targets assets prior the financial crisis and subsequent revaluations compounded their under-performance.

Examination of the prior research makes it difficult to draw strong conclusions on the postannouncement performance. On average, the results across varying methods of measuring long-term returns suggest market inefficiency. However, Fama (1998) argues that market efficiency should not be discarded. He suggests that an efficient market produces different types of events that individually cause share prices to over or under-react. The under-reaction will be approximately as frequent as the over-reaction in an efficient market. If these anomalies are split randomly between each other, they are consistent with market efficiency.

Furthermore, it appears that the long-term return anomalies that suggest market inefficiency are sensitive to a number of factors. These include the different time periods studied and possibly the different datasets, the methodology employed (Bessembinder and Zhang, 2013, Martynova and Renneboog, 2008) and the different markets examined (e.g. US versus Europe).

The contribution this paper makes is to provide an analysis of post-announcement performance in the REIT sector, which takes into account significant periods of adjustments. The impacts of dramatic changes in the economic and regulatory environments have not been studied in depth. This paper provides a detailed study of these impacts in relation to the post-announcement period. The study employs both BHAR and three-factor methodologies and by examining the post-announcement performance within the same industry decreases possible 'inaccuracies resulting from missing pricing factors that may have varying effects across industries’ (Campbell, Giambona and Sirmans, 2009). 


\section{DATA COLLECTION AND METHODOLOGY}

\section{Data Collection}

Post-announcement excess returns for US equity REIT acquirers are calculated over the one, two and three-year event periods. The sample period for the study extends from January 2000 to September 2014. January 2000 was selected as the starting period due to the introduction of the REIT Modernization Act 1999. As discussed in the introduction, Howe and Jain (2004) argue that the Act transformed REITs, impacting on their profitability, growth and risk. We searched successful equity REIT M\&A announcements where the deal value was in excess of $\$ 50$ million within the Bloomberg Database and crosschecked the announcements with National Association of Real Estate Investments Trusts merger data. Share price data and book value data was collected via both the Bloomberg and Thomson Reuters Databases.

The initial data search identified 97 successful M\&A announcements. The study then employed the following screening process to isolate the final sample:

- $\quad$ REIT monthly share prices must be available for a minimum period of twelve months after the announcement month, to a maximum of 36 months;

- $\quad$ accounting data available for acquirers on December 31 the year prior the announcement; and,

- there must be an absence of large-scale confounding events occurring during the postannouncement period. ${ }^{5}$

Insufficient price and accounting data resulted in the removal of 25 announcements and a further nine were removed due to the announcement overlapping with subsequent announcements. After screening we observe 63 M\&A announcements for the one-year event window. The two-year window comprises 49 observations, while the three-year period contains 35 observations. The differences in the number of observations across the three periods are due to the final filtering requirement. More specifically, if a bidder makes an announcement in July 2001 and another in October 2002, the 2001 announcement would only be included in the one-year excess return calculations. The abnormal returns would not be calculated for the two and three-year periods because they overlap the October 2002 announcement. However, the October 2002 announcement has no overlapping post-announcement periods and therefore excess returns would be calculated for the one, two and three-year event windows. 
In relation to the buy-and-hold methodology, the study also required the construction of a matching/control portfolio. The control firms are selected from the equity REIT sector and are subject to the same filtering processes described above, with the additional constraint that the control firm is not involved in a M\&A during the sample period.

Table 1 presents the descriptive statistics for the acquiring sample. It can be seen that REIT bidders are, on average, larger than the acquisition value ( $\$ 5.1$ billion versus $\$ 2.4$ billion). Campbell, Ghosh, Petrova and Sirmans (2011) and Eichholtz and Kok (2008) both observed REIT bidders were, on average, approximately twice the size of the acquisition value in their short-term studies on REIT M\&As. Mean book-to-market ratio shows that REIT acquirers were, on average, trading at a premium to Net Tangible Assets (NTA) prior the announcement, suggesting that the bidders are in a healthy financial position. This outcome is consistent with Campbell, Giambona and Sirmans (2009) who also observed REIT bidders were trading at a premium to NTA prior the announcement.

\section{$<<$ INSERT TABLE 1 ABOUT HERE $>>$}

Figure 1 shows the equity REIT M\&A announcements by year employed in the study. It can be seen that consolidation activity within the sector peaked in 2006. However, from 2007 to 2009 there was a distinct slowdown in announcements and no M\&A observations in 2009 as the impacts of the financial crisis took effect on REITs. Martynova and Renneboog (2008, p. 2419) suggest that M\&A activity "is usually disrupted by a steep decline in stock markets and a sub-sequent recession”.

\section{$<<$ INSERT FIGURE 1 ABOUT HERE $>>$}

\section{Methodology}

Two types of methodologies have been employed in this study, buy-and-hold abnormal returns and the three-factor model. Prior research indicates mixed results utilizing the various methods. As described in the literature review, Barber and Lyon (1997) and Lyon, Barber and Tsai (1999) document that the use of the BHAR method is superior to the CARs method when assessing long-term performance. On the other hand, Mitchell and Stafford (2000) and Bouwman, Fuller and Nain (2009) both advocate the use of the three-factor model. Mitchell and Stafford (2000) argue that there is cross-sectional correlation of individual event firms when estimating long-term abnormal returns. Bouwman, Fuller 
and Nain (2009) argue that employing the three-factor model automatically accounts for cross-sectional correlations in the portfolio variance at each point in time.

Given the discussions regarding the most appropriate methodology, this study employs both methodologies. This will enable the study to test the robustness of the post-announcement performance of REIT acquirers. Consistent with short-term event studies, we first have to identify the date of the M\&A announcement. Following Campbell, Giambona and Sirmans (2009), the event month $[t=0]$ for the study is set as the month end in which the M\&A is announced.

\section{Buy-and-Hold Abnormal Returns}

To calculate BHARs an appropriate benchmark (non-event) control portfolio is required. We follow the methodology presented by Campbell, Giambona and Sirmans (2009) to develop the non-event control portfolio. First, we identify all non-event REIT firms available for the study period. The non-event REITs are then ranked on market size and book-to-market value. Market size is calculated as the number of shares on issue times the closing share price one calendar month before the event occurrence. Book-to-market is calculated as the firm's book value, divided by the market value of the firm reported in their annual report prior to the M\&A announcement.

Each REIT bidder is then matched to three non-event REITs that are closely equivalent to the bidding REIT in terms of size and book-to-market. ${ }^{6}$ The control portfolio is then matched to the event firm for the full buy-and-hold period.

The BHARs are calculated as the difference between the compounded monthly returns over the event period of the event firm less the control portfolio:

$$
B H A R_{i}=\prod_{t=1}^{T}\left(1+R_{i, t}\right)-\left(B H R_{R P, i}\right)
$$

Where:

$$
B H R_{R P, i}=\sum_{j=1}^{n} \frac{\left[\prod_{t=1}^{T}\left(1+R_{j, t}\right)\right]}{n}
$$

$B H A R_{i}$ is the buy-and-hold abnormal return for event firm $i$ over the time period $T$; 
$R_{i, t}$ is the monthly total return for event firm $i$ in month $t$;

$R_{j, t}$ is the monthly total return for non-event firm $j$ in month $t$;

$n$ is the number of non-event firms that make up the control portfolio; and

$B H R_{R P, i}$ is the arithmetic average compounded monthly return of the control portfolio.

The statistical significance of the BHARs is calculated for each event window. This study employs two statistical tests to assess the robustness of the BHARs significance. The first is a traditional test statistic:

$$
t_{B H A R}=\frac{\overline{B H A R_{T}}}{\sigma\left(B H A R_{T}\right) / \sqrt{N}}
$$

Where:

$\overline{B H A R}_{T}$ is the sample mean BHAR calculated over time period $T$;

$\sigma\left(B H A R_{T}\right)$ is the cross-sectional sample standard deviation; and

$N$ is the number of event observations.

Barber and Lyon (1997) provide evidence that long-term BHARs are positively skewed resulting in negatively biased $t$-statistics. To adjust for the potential skewness bias when BHARs are calculated using control portfolio, Lyon, Barber and Tsai (1999) advocate the use of a skewness-adjusted $t$ statistic:

$$
t_{s a}=\sqrt{N}\left(S+\frac{1}{3} \hat{\gamma} S^{2}+\frac{1}{6 N} \hat{\gamma}\right)
$$

Where:

$$
S=\frac{\overline{B H A R}_{T}}{\sigma\left(B H A R_{T}\right)}
$$

and, 


$$
\hat{\gamma}=\frac{\sum_{i=n}^{n}\left(B H A R_{i t}-\overline{B H A R_{T}}\right)^{3}}{N \sigma\left(B H A R_{T}\right)^{3}}
$$

The calculation of $\hat{\gamma}$ is an estimate of the coefficient of skewness and $\sqrt{N} S$ is the standard $t$-statistic of equation (3) (Lyon, Barber and Tsai, 1999).

\section{Fama-French Three-Factor Model}

The second methodology employed to identify post-announcement performance is the three-factor model developed by Fama and French (1993). Asset pricing research has shown that the three-factor model has strong empirical support in determining share price movements (Brailsford, Gaunt and O'Brien, 2012). The three-factor model is implemented by regressing the post-announcement monthly excess returns of the acquiring firm against a market factor, a size factor and a book-to-market factor:

$$
R_{i, t}-R_{f, t}=\alpha_{i}+\beta_{i} R M R F_{t}+s_{i} S M B_{t}+h_{i} H M L_{t}+\varepsilon_{i, t}
$$

Where:

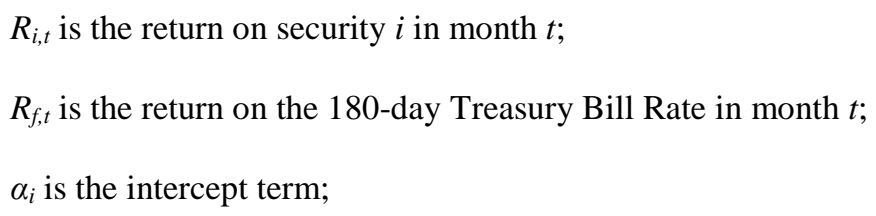

The intercept, $\alpha_{i}$, is the variable of interest in the model and measures the mean monthly abnormal return of the event firm. A positive intercept indicates the sample firm has outperformed, after controlling for market, size and book-to-market factors (Barber and Lyon, 1997).

As the focus of this study is the equity REIT sector, the calculation of the factors is developed from the equity REIT universe. Excluding conventional firms from the estimation of the factors removes any possible noise within the factors that may not be relevant to the REIT sector. The market index employed is the FTSE NAREIT All Equity REITs Index. The calculation of the SMB and HML factors follows Fama and French (1993) and Brailsford, Gaunt and O'Brien (2012). 


\section{RESULTS AND DISCUSSION}

\section{BHAR Results}

The BHAR results for REIT bidders are presented in Table 2. Panel A shows the excess returns for the full study period. Acquirers earn positive, but insignificant, BHARs across the three event windows. This outcome suggests that the anomaly of post-merger underperformance does not hold for REITs. In addition, the result supports the argument by Eichholtz and Kok (2008) that, due to their regulatory environment, REITs may be less vulnerable to agency problems. Our results are consistent with prior REIT research by Sahin (2005) who observed insignificant BHARs of $+3.56 \%$ over the three-year event period.

\section{$<<$ INSERT TABLE 2 ABOUT HERE $>>$}

The full sample period covers the financial crisis, to examine the impacts of the crisis on the long-term performance of REIT bidders, the sample was divided into pre- and post-crisis. Figure 2 displays the FTSE NAREIT All Equity REITs Index over the study period. ${ }^{7}$ The index reached a month-end high of 10,526.96 in January 2007 before the onset of the crisis. The cut-off month is consistent with prior REIT studies examining the impacts of the crisis on REIT performance (Simon and Ng, 2009, Sun, Titman and Twite, 2015).

\section{$<<$ INSERT FIGURE 2 ABOUT HERE $>>$}

Panels B and C of Table 2 present the BHARs for announcements occurring pre- and post-January 2007. Pre-crisis results show that REIT bidders earn positive and significant mean BHARs across all three-event windows. Ranging from $+10.72 \%$ in the one-year period to $+24.04 \%$ for the three-year window. In addition, the median BHARs are also positive and significant across all periods. This outcome suggest that prior to the structural break, due to the financial crisis, that REIT M\&As were motivated by synergy.

The low interest rate environment post-2000 and rising commercial property prices may have contributed to acquirer excess returns (Barclays, 2012). In addition, Lee (2010) indicates that after the Modernization Act, larger REITs became more desirable to institutional investors. Ciochetti, Craft and Shilling (2002) argue that institutional investors prefer larger and more liquid REITs because it allows 
them to buy and sell large positions without affecting share prices. Campbell, Ghosh, Petrova and Sirmans (2011) suggests that mergers are a useful way to increase firm size, and improve market depth. Devos, Ong and Spieler (2007) observed a positive relationship between REIT value and analyst coverage. While Goebel, Harrison, Mercer and Whitby (2013) revealed a positive relationship between analyst coverage and institutional investors. It is hypothesized, given these factors, acquiring REITs were able to increase their property holdings (in a rising market) and at the same time attract institutional investment resulting in positive abnormal returns.

Panel C shows that acquirers earn negative BHARs across all three-event windows in the post-crisis period. However, only the two-year mean BHAR displays statistical significance $(-9.45 \%$, $p$-value $<$ 5\%). This result highlights the structural change in the REIT sector as a result of the financial crisis. Betton, Eckbo and Thorburn (2007) suggest that negative post-announcement excess returns may be due to a negative regulatory shock. However, it would be expected that a shock like the financial crisis would impact on non-merged firms as well. The post-crisis abnormal returns may be a result of the high volatility and uncertainty in the sector during the crisis period, making it difficult for acquirers to integrate the assets of the targets and achieve any possible synergistic benefits.

In addition, Kawaguchi, Sa-Aadu and Shilling (2012) indicate that REITs increased their risk levels, via increased leverage, before the crisis, taking advantage of the low interest rate environment of the mid-2000s. At the same time commercial property values increased greatly from 2004 to 2007 leading to "one of the largest commercial real estate bubbles in history" (Barclays, 2012, p. 25). The onset of the crisis saw a decline in commercial property values, resulting in REITs trading at a discount to NTA and an increase in vacancies (Block, 2012). It is hypothesised that, in addition to the problems with integrating targets assets, unintentional over-payment for property assets prior the crisis and the subsequent fall in property prices compounded acquirers underperformance.

\section{Three-Factor Abnormal Returns Results}

Table 3 presents the abnormal returns from the three-factor model methodology. Panel A reports the results for the full study period. Consistent with the BHAR results, we do not find significant excess returns over the full study period. Panel B shows the three-factor results for the pre-crisis period. The intercept for both the one- and two-year event windows are positive and significant. One-year monthly excess returns are $0.6 \%$, equating to an annual abnormal return of $7.2 \%$ and the two-year excess return 
is $12 \%$ ( $0.5 \%$ monthly return). These results support the findings of the BHAR methodology and the synergy motive for REIT acquisitions, prior to the financial crisis and hence adding value to shareholders in the long-term.

$<<$ INSERT TABLE 3 ABOUT HERE $>>$

Panel C shows the three-factor excess returns for post-January 2007. The intercept is negative across all three periods, consistent with the BHAR results. However, only the one-year model is statistically significant. Acquirers earn a mean monthly abnormal return of $-0.8 \%$, which equates to an annual abnormal return of $-9.6 \%$. This result further supports the hypothesis that REIT bidders experienced significant under-performance possibly due to over-payment for property assets, increased uncertainty in the sector during the crisis and integration of the targets assets. The results in the post-January 2007 sub-period across both methods imply that REIT M\&As were driven by the hubris motives. The differing results across both sub-periods raises the issue of motivation in the REIT sector. It is hypothesized that REIT M\&A motivation is not static and is influenced by external macro-economic events. The shift from synergy to hubris motivations is an example of how this may occur.

\section{CONCLUSIONS}

This study extends the prior US REIT post-announcement research by Sahin (2005) and Campbell, Giambona and Sirmans (2009) with a later dataset that incorporates the effects of the financial crisis. Both the BHARs and the three-factor model abnormal returns of REIT M\&As from 2000 to 2014 are measured. Results over the full sample period show, in contrast to the majority of research on conventional firms, that REIT bidders do not underperform in the three-years post-announcement.

The study lends support to the hypothesis put forward by Fama (1998), that markets may experience anomalies in returns and still be regarded as informationally efficient. Within the study period, changes in regulation and the business environment altered longer-term outcomes. Whereas previous studies have suggested that the market tended towards weak form efficiency, the current study indicates that this is not necessarily a permanent feature of the REIT sector. Market adjustment to the changing economic landscape improved bidder returns suggesting greater levels of information efficiency. This result also supports the synergy motive for M\&As in the REIT sector. The low interest rate environment of the period, the focus to increase size to attract institutional investors and rising commercial property prices may have contributed to the positive excess returns. 
We accept that although this study has employed two methods to assess post-announcement performance, it can be difficult to isolate the pure M\&A effect from other events that may have occurred in the event window and therefore impacted on the results. The pre-crisis results, however, from both methodologies are consistent with the synergy motive. The financial crisis had a significant impact on the REIT sector; the effects observed in this study have shown negative and significant excess returns. Further investigation in the post-crisis era may add more clarification to the Fama (1998) hypothesis and the impact of structural changes in the market. In addition, we feel further research into REIT regimes globally will also add to our understanding of the post-announcement performance of REITs. 


\section{ENDNOTES}

1. Langetieg (1978) discusses that the assumption of stationary betas in the market model, biases in measurement errors, model specification errors and other common non-merger influences can impact the observed excess returns.

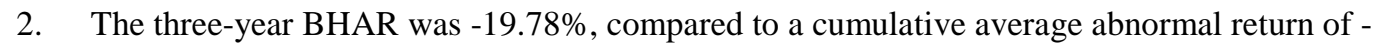
$14.4 \%$ for the three-factor model.

3. Sahin (2005) utilized the factors provided by Kenneth R. French that are derived for the market as a whole, which may have introduced distortion from other sectors into the modeling resulting in differences in the BHAR results and the three-factor model.

4. The market factors in the study were derived from the A-REIT universe and not the general market. The authors cited that the use of A-REIT factors removes possible noise within the factors that may not be relevant to A-REITs.

5. For example, a firm that is involved in multiple M\&As that occur, at a minimum, within one-year of each other will require the removal of the earlier announcement, as the data collection period covers the later announcement. Lyon, Barber and Tsai (1999) claim a lack of independence is generated from overlapping returns, yielding mis-specified test statistics.

6. Barber and Lyon (1997) describe the parameters for matching the event firm to the portfolio should lie within the range of $70 \%$ to $130 \%$ of size and book-to-market value. Attempting to match bidding REITs by property type would have made it difficult for the control group to meet the parameters of $70 \%$ to $130 \%$.

7. The Index was set to a base of 100 in January 2000. 


\section{REFERENCES}

Agrawal, A. and J. Jaffe, The Post-Merger Perfromance Puzzle, In C. Cooper and A. Gregory, editor, Advances in Mergers and Acquisitions, Bradford:Emerald Group Publishing, 2000, 7-41.

Alexandridis, G., A. Antoniou and H. Zhao, Valuation effects of short sale constraints: the case of corporate takeovers, European Financial Management, 2006, 12:5, 747-762.

Alexandridis, G., C.F. Mavrovitis and N.G. Travlos, How have M\&As changed? Evidence from the sixth merger wave, European Journal of Finance, 2012, 18:8, 663-688.

Anderson, R.I., H. Medla, N.B. Rottke and D. Schiereck, Real estate merger motives: an analytical review of the literature, Journal of Real Estate Literature, 2012, 20:1, 37-47.

André, P., M. Kooli and J.-F. L'Her, The long-run performance of mergers and acquisitions: evidence from the Canadian stock market, Financial Management, 2004, 33:4, 27-43.

Ang, J., C. Yingmei and G. Nagel, An analysis of acquirers as dealmakers: differentiating acquirers' timing, bargain hunting and negotiating skills, Journal of Mergers and Acquisitions, 2008, 5:4, 7-33.

Barber, B.M. and J.D. Lyon, Detecting long-run abnormal stock returns: The empirical power and specification of test statistics, Journal of Financial Economics, 1997, 43:3, 341-372.

Barclays, $\quad$ REITs 101: An introduction, htp://urbanland.uli.org/wpcontent/uploads/sites/5/2013/10/USREITs_REITs_101_An_Introduction.pdf, 2012.

Berkovitch, E. and M.P. Narayanan, Motives for Takeovers: An Empirical Investigation, Journal of Financial \& Quantitative Analysis, 1993, 28:3, 347-362.

Bessembinder, H. and F. Zhang, Firm characteristics and long-run stock returns after corporate events, Journal of Financial Economics, 2013, 109:1, 83-102.

Betton, S., E. Eckbo and K. Thorburn, Corporate Takeovers, In E. Eckbo, editor, Handbook of Corporate Finance: Empirical Corporate Finance, Amsterdam:Elsevier/North Holland, 2007,

Block, R.L., Investing in REITs : Real Estate Investment Trusts, 4th edition, Hoboken, N.J.:Bloomberg Press/Wiley, 2012.

Bouwman, C.H.S., K. Fuller and A.S. Nain, Market valuation and acquisition quality: empirical evidence, Review of Financial Studies, 2009, 22:2, 633-679.

Brailsford, T., C. Gaunt and M. O'Brien, Size and book-to-market factors in Australia, Australian Journal of Management, 2012, 37:2, 261-81.

Campbell, R.D., C. Ghosh, M. Petrova and C.F. Sirmans, Corporate governance and performance in the market for corporate control: the case of REITs, Journal of Real Estate Finance \& Economics, 2011, 42:4, 451-480.

Campbell, R.D., E. Giambona and C.F. Sirmans, The long-horizon performance of REIT mergers, Journal of Real Estate Finance \& Economics, 2009, 38:2, 105-114. 
Ciochetti, B.A., T.M. Craft and J.D. Shilling, Institutional Investors' Preferences for REIT Stocks, Real Estate Economics, 2002, 30:4, 567-593.

Conn, R.L., A. Cosh, P.M. Guest and A. Hughes, The impact on UK acquirers of domestic, crossborder, public and private acquisitions, Journal of Business Finance and Accounting, 2005, 32:5/6, 815-870.

Cosh, A. and P.M. Guest, The long run performance of hostile takeovers: UK evidence, working paper, ESRC Centre for Business Research, 2001

Croci, E., D. Petmezas and E. Vagenas-Nanos, Managerial overconfidence in high and low valuation markets and gains to acquisitions, International Review of Financial Analysis, 2010, 19:5, 368-378.

Datta, S., D. Kodwani and H. Viney, Shareholder wealth creation following M\&A: evidence from European utility sectors, Applied Financial Economics, 2013, 23:10, 891-900.

Devos, E., S. Ong and A. Spieler, Analyst Activity and Firm Value: Evidence from the REIT Sector, The Journal of Real Estate Finance and Economics, 2007, 35:3, 333-356.

Dodd, P., Merger proposals, manageement discretion and stockholder wealth, Journal of Financial Economics, 1980, 8:2, 105-138.

Dodd, P. and R.S. Ruback, Tender offers and stockholder returns : an empirical analysis, Journal of Financial Economics, 1977, 5:3, 351-373.

Dutta, S. and V. Jog, The long-term performance of acquiring firms: a re-examination of an anomaly, Journal of Banking and Finance, 2009, 33:8, 1400-12.

Eichholtz, P.M.A. and N. Kok, How does the market for corporate control function for property companies?, Journal of Real Estate Finance and Economics, 2008, 36:2, 141-163.

Ellert, J.C., Mergers, antitrust law enforcement and stockholder returns, Journal of Finance, 1976, 31:2, 715-732.

Fama, E.F., Market efficiency, long-term returns, and behavioral finance, Journal of Financial Economics, 1998, 49:3, 283-306.

Fama, E.F. and K.R. French, Common risk factors in the returns on stocks and bonds, Journal of Financial Economics, 1993, 33:1, 3-56.

Gaspar, J.-M., M. Massa and P. Matos, Shareholder investment horizons and the market for corporate control, Journal of Financial Economics, 2005, 76:1, 135-165.

Goebel, P., D. Harrison, J. Mercer and R. Whitby, REIT Momentum and Characteristic-Related REIT Returns, Journal of Real Estate Finance \& Economics, 2013, 47:3, 564-581.

Gregory, A., An examination of the long run performance of UK acquiring firms, Journal of Business Finance and Accounting, 1997, 24:7/8, 971-1002.

Higson, C. and J. Elliott, Post-takeover returns: the UK evidence, Journal of Empirical Finance, 1998, $5: 1,27-46$. 
Howe, J. and R. Jain, The REIT Modernization Act of 1999, The Journal of Real Estate Finance and Economics, 2004, 28:4, 369-388.

Jensen, M.C., Agency cost of free cash flow, corporate finance, and takeovers, American Economic Review, 1986, 76:2, 323-329.

Jensen, M.C. and R.S. Ruback, The market for corporate control, Journal of Financial Economics, 1983, 11:1, 5-50.

Kawaguchi, Y., J. Sa-Aadu and J. Shilling, REIT stock price volatility during the financial crisis, Paper presented at the 17th Asian Real Estate Society Conference, April 2012.

Kiymaz, H. and H.K. Baker, Short-term performance, industry effects, and motives: evidence from large M\&As, Quarterly Journal of Finance and Accounting 2008, 47:2, 17-44.

Kothari, S.P. and J.B. Warner, Measuring long-horizon security price performance, Journal of Financial Economics, 1997, 43:3, 301-339.

Langetieg, T., An application of a three-factor performance index to measure stockholders gains from merger, Journal of Financial Economics, 1978, 6:4, 365-384.

Latorre, M.A., B. Herrero and J.E. Farinós, Do acquirers’ stock prices fully react to the acquisition announcement of listed versus unlisted target firms? Out-of-sample evidence from Spain, Applied Economics Letters, 2014, 21:15, 1075-1078.

Lee, S.L., The Changing Benefit of REITs to the Mixed-Asset Portfolio, Journal of Real Estate Portfolio Management, 2010, 16:3, 201-215.

Limmack, R.J., Discussion of an examination of the long run performance of UK acquiring firms, Journal of Business Finance and Accounting, 1997, 24:7/8, 1003-1007.

Loughran, T. and J.R. Ritter, Uniformly least powerful tests of market efficiency, Journal of Financial Economics, 2000, 55:3, 361-389.

Lyon, J.D., B.M. Barber and C.-L. Tsai, Improved methods for tests of long-run abnormal stock returns, Journal of Finance, 1999, 54:1, 165-201.

Malatesta, P.H., The wealth effect of merger activity and the objective functions of merging firms, Journal of Financial Economics, 1983, 11:1-4, 155-181.

Manne, H.G., Mergers and the market for corporate control, Journal of Political Economy, 1965, 73:2, 110-120.

Martynova, M. and L. Renneboog, A century of corporate takeovers: What have we learned and where do we stand?, Journal of Banking and Finance, 2008, 32:10, 2148-2177.

Mitchell, M.L. and E. Stafford, Managerial decisions and long-term stock price performance, Journal of Business, 2000, 73:3, 287-329.

Moeller, S.B., F.P. Schlingemann and R.M. Stulz, Firm size and gains from acquisitions, Journal of Financial Economics, 2004, 73:2, 201-228. 
Morck, R., A. Shleifer and R. Vishny, Do managerial objectives drive bad acquisitions, Journal of Finance, 1990, 45:1, 31-48.

Ratcliffe, C., B. Dimovski and M. Keneley, Long-term post-merger announcement perfromance: A case study of Australian listed real estate, Accounting \& Finance, 2015, doi:10.1111/acfi.12184.

Roll, R., The hubris hypothesis of corporate control, Journal of Business, 1986, 59:2, 197-216.

Sahin, O.F., The performance of acquisitions in the Real Estate Investment Trust industry, Journal of Real Estate Research, 2005, 27:3, 321-42.

Savor, P.G. and Q.I. Lu, Do stock mergers create value for acquirers?, Journal of Finance, 2009, 64:3, 1061-1097.

Simon, S. and W.L. Ng, The Effect of the Real Estate Downturn on the Link between REITs and the Stock Market, Journal of Real Estate Portfolio Management, 2009, 15:3, 211-219.

Sudarsanam, S., P. Holl and A. Salami, Shareholder wealth gains in mergers: Effects of synergy and ownership structure, Journal of Business Finance and Accounting, 1996, 23:5/6, 673-698.

Sudarsanam, S. and A.A. Mahate, Glamour acquirers, method of payment and post-acquisition performance: the UK evidence, Journal of Business Finance and Accounting, 2003, 30:1/2, 299-341.

Sun, L., S.D. Titman and G.J. Twite, REIT and Commercial Real Estate Returns: A Postmortem of the Financial Crisis, Real Estate Economics, 2015, 43:1, 8-36. 
Exhibit 1 Descriptive statistics for equity REIT M\&A announcements.

\begin{tabular}{lccc}
\hline & M\&A Characteristics (\$M) & Bidder Size (\$M) & Bidder Book-to-Market \\
\hline Mean & $2,430.68$ & $5,082.60$ & 0.5367 \\
Median & $1,097.00$ & $3,449.40$ & 0.4926 \\
Min & 58.80 & 70.10 & 0.0371 \\
Max & $16,517.00$ & $24,343.38$ & 1.2598 \\
Skewness & 2.4093 & 1.7375 & 0.6851 \\
Kurtosis & 8.3916 & 2.7184 & 0.5007 \\
No. Obs & 63 & \\
Notes: Descriptive statistics for M\&A deal characteristics, acquirer size and book-to-market ratio for REIT \\
announcements from January 2000 to September 2014. \\
\hline
\end{tabular}


Exhibit 2 REIT M\&A announcements.

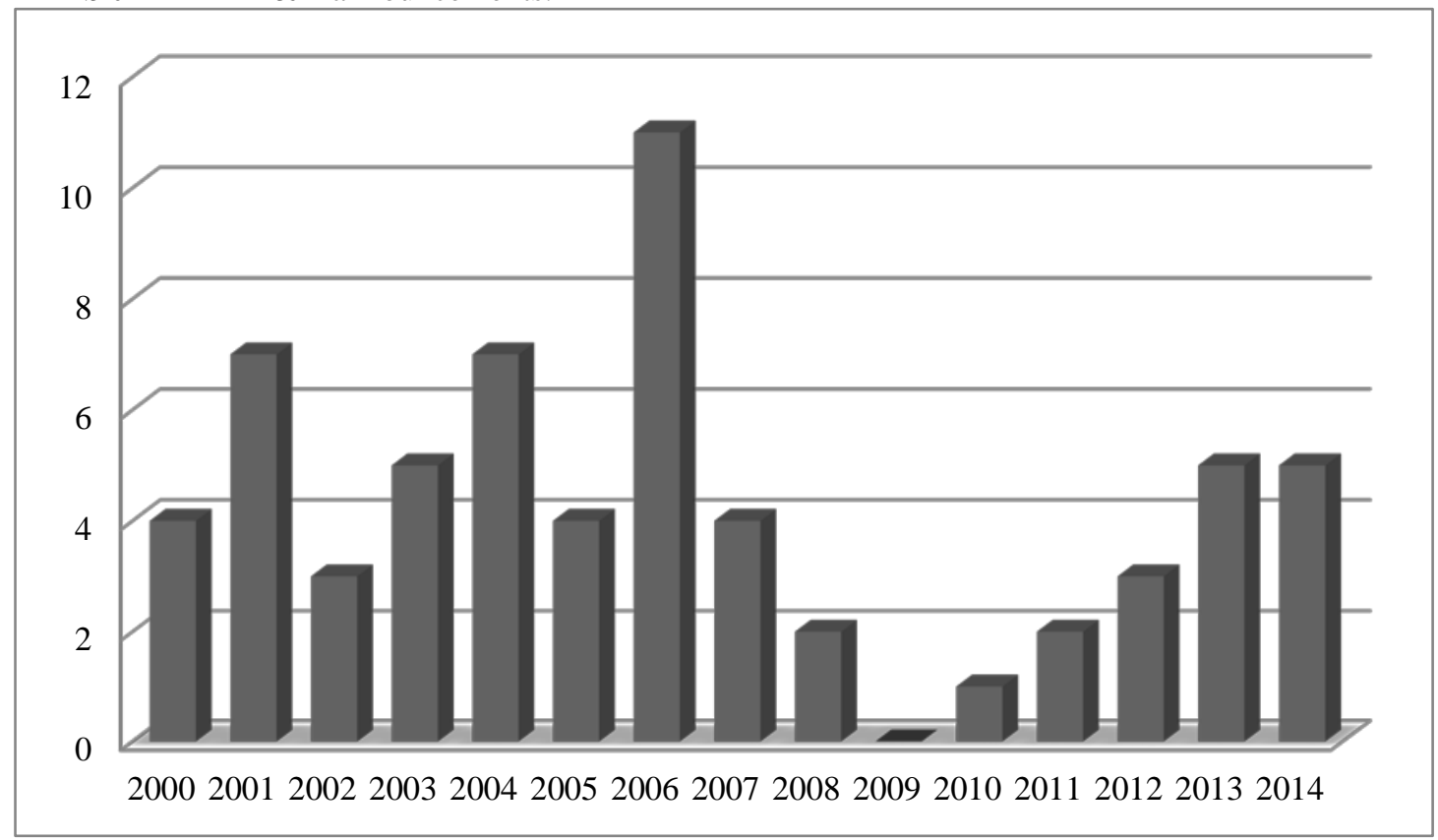

Graph of REIT M\&A announcements employed in the study by year. 
Exhibit 3 FTSE NAREIT Equity REIT Index.

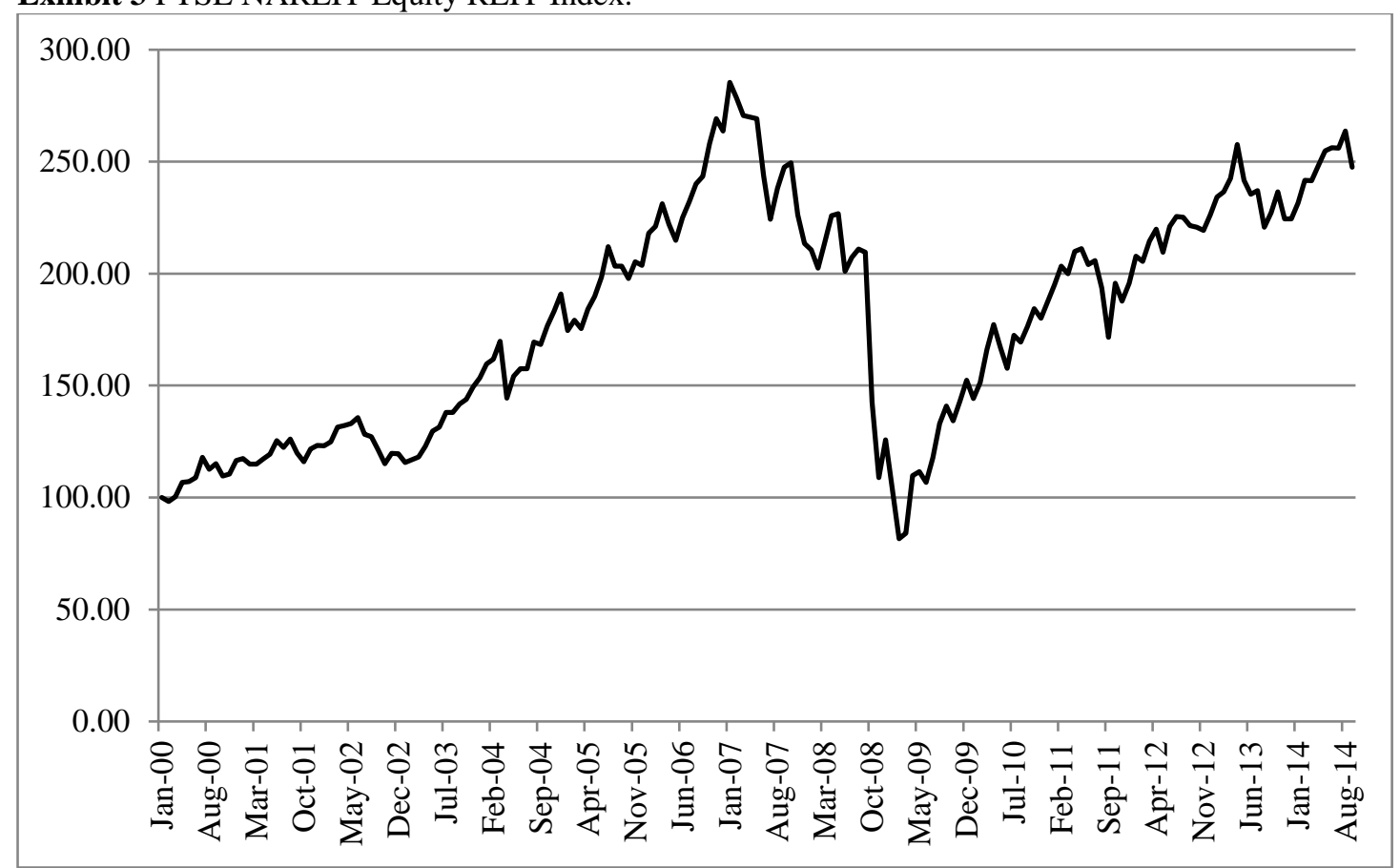

Graph of the FTSE NAREIT Equity REIT Index, January 2000 to September 2014.

The index was set to a base value of 100 in January 2000. Source: NAREIT (https://www.reit.com/nareit). 
Exhibit 4 REIT Acquirer Buy-and-Hold Abnormal Returns.

\begin{tabular}{|c|c|c|c|}
\hline & One Year & Two Year & Three Year \\
\hline \multicolumn{4}{|l|}{ Panel A: Full Sample } \\
\hline Mean BHAR & $+3.45 \%$ & $+1.65 \%$ & $+2.79 \%$ \\
\hline (P-value) & $(0.263)$ & $(0.732)$ & $(0.692)$ \\
\hline (Skewness-adjusted p-value) & $(0.231)$ & $(0.710)$ & $(0.684)$ \\
\hline Median BHAR & $+0.76 \%$ & $-1.26 \%$ & $-0.56 \%$ \\
\hline (P-value) & $(0.806)$ & $(0.794)$ & $(0.937)$ \\
\hline (Skewness-adjusted p-value) & $(0.781)$ & $(0.820)$ & $(0.949)$ \\
\hline Number Observations & 63 & 46 & 38 \\
\hline \multicolumn{4}{|l|}{ Panel B: Pre-Jan 2007} \\
\hline Mean BHAR & $+10.72 \%$ & $+17.43 \%$ & $+24.04 \%$ \\
\hline (P-value) & $(0.004)^{* * *}$ & $(0.036)^{* *}$ & $(0.045)^{* *}$ \\
\hline (Skewness-adjusted p-value) & $(0.000)^{* * *}$ & $(0.003)^{* * *}$ & $(0.004)^{* * *}$ \\
\hline Median BHAR & $+9.46 \%$ & $+21.36 \%$ & $+20.74 \%$ \\
\hline (P-value) & $(0.011)^{* *}$ & $(0.010)^{* *}$ & $(0.083)^{*}$ \\
\hline (Skewness-adjusted p-value) & $(0.001)^{* * *}$ & $(0.000)^{* * *}$ & $(0.017)^{* *}$ \\
\hline Number Observations & 30 & 19 & 14 \\
\hline \multicolumn{4}{|l|}{ Panel C: Post-Jan 2007} \\
\hline Mean BHAR & $-3.17 \%$ & $-9.45 \%$ & $-9.59 \%$ \\
\hline (P-value) & $(0.486)$ & $(0.049)^{* *}$ & $(0.243)$ \\
\hline (Skewness-adjusted p-value) & $(0.516)$ & $(0.002)^{* * *}$ & $(0.182)$ \\
\hline Median BHAR & $-2.11 \%$ & $-6.26 \%$ & $-5.75 \%$ \\
\hline (P-value) & $(0.642)$ & $(0.193)$ & $(0.484)$ \\
\hline (Skewness-adjusted p-value) & $(0.667)$ & $(0.135)$ & $(0.431)$ \\
\hline Number Observations & 22 & 20 & 18 \\
\hline \multicolumn{4}{|c|}{$\begin{array}{l}\text { Notes: This table shows the mean and median buy-and-hold abnormal returns (BHAR) for acquiring REITs over } \\
\text { the study period of January } 2000 \text { to September 2014. BHARs are calculated over the one, two and three-year } \\
\text { post-announcement periods. Panel A shows the BHARs calculations for full sample period. Panel B shows the } \\
\text { BHARs calculations up to January } 2007 \text {. Panel C shows all BHAR calculations that occurred after January } 2007 . \\
\text { BHARs are calculated using the size and market-to-book matching as described by Lyon, Barber and Tsai } \\
\text { (1999). } P \text {-values are calculated using a standard } t \text {-statistic and a skewness-adjusted } t \text {-statistic. ***, **, * show } \\
\text { statistical significance at the } 1 \%, 5 \% \text { and } 10 \% \text { level respectively. }\end{array}$} \\
\hline
\end{tabular}


Exhibit 5 REITs Three-Factor Model Abnormal Returns.

\begin{tabular}{|c|c|c|c|c|c|c|}
\hline & \multicolumn{2}{|c|}{ One Year } & \multicolumn{2}{|c|}{ Two Year } & \multicolumn{2}{|c|}{ Three Year } \\
\hline & Coef. & (p-val) & Coef. & (p-val) & Coef. & (p-val) \\
\hline \multicolumn{7}{|l|}{ Panel A: Full Sample } \\
\hline INTERCEPT & -0.002 & $(0.555)$ & -0.001 & $(0.850)$ & -0.001 & $(0.611)$ \\
\hline RMRF & 0.936 & $(0.000)^{* * *}$ & 0.965 & $(0.000)^{* * *}$ & 0.985 & $(0.000)^{* * *}$ \\
\hline SMB & 0.284 & $(0.016)^{* *}$ & 0.073 & $(0.453)$ & -0.064 & $(0.499)$ \\
\hline HML & 0.098 & $(0.375)$ & 0.328 & $(0.000)^{* * *}$ & 0.390 & $(0.000)^{* * *}$ \\
\hline$R^{2}$ & 0.265 & & 0.348 & & 0.466 & \\
\hline $\operatorname{Adj} . R^{2}$ & 0.262 & & 0.346 & & 0.465 & \\
\hline Number Observations & 756 & & 1104 & & 1368 & \\
\hline \multicolumn{7}{|l|}{ Panel B: Pre-Jan 2007} \\
\hline INTERCEPT & 0.006 & $(0.013)^{* *}$ & 0.005 & $(0.017)^{* *}$ & 0.001 & $(0.743)$ \\
\hline RMRF & 0.901 & $(0.000)^{* * *}$ & 0.897 & $(0.000)^{* * *}$ & 0.870 & $(0.000)^{* * *}$ \\
\hline SMB & -0.088 & $(0.432)$ & -0.061 & $(0.566)$ & -0.064 & $(0.536)$ \\
\hline HML & -0.111 & $(0.355)$ & -0.007 & $(0.947)$ & 0.072 & $(0.504)$ \\
\hline$R^{2}$ & 0.428 & & 0.424 & & 0.431 & \\
\hline Adj. $R^{2}$ & 0.423 & & 0.421 & & 0.427 & \\
\hline Number Observations & 372 & & 456 & & 504 & \\
\hline \multicolumn{7}{|l|}{ Panel C: Post-Jan 2007} \\
\hline INTERCEPT & -0.008 & $(0.073)^{*}$ & -0.004 & $(0.331)$ & -0.006 & $(0.190)$ \\
\hline RMRF & 0.941 & $(0.000)^{* * *}$ & 0.989 & $(0.000)^{* * *}$ & 0.869 & $(0.000)^{* * *}$ \\
\hline SMB & 0.506 & $(0.016)^{* *}$ & 0.273 & $(0.147)$ & -0.109 & $(0.528)$ \\
\hline HML & 0.262 & $(0.119)$ & 0.399 & $(0.008)^{* * *}$ & 0.468 & $(0.001)^{* * *}$ \\
\hline$R^{2}$ & 0.202 & & 0.336 & & 0.392 & \\
\hline $\operatorname{Adj} . R^{2}$ & 0.196 & & 0.332 & & 0.390 & \\
\hline Number Observations & 384 & & 648 & & 864 & \\
\hline \multicolumn{7}{|c|}{$\begin{array}{l}\text { Notes: This table presents the results of the three-factor model ordinary least squares regression using monthly } \\
\text { data for REIT bidders over the sample period of } 2000 \text { to } 2014 \text {. RMRF is the excess return on the All Equity REIT } \\
\text { index, SMB is the return difference between a portfolio of small and large REITs, HML is return difference } \\
\text { between the portfolios of high and low book-to-market REITs. The INTERCEPT measures the mean monthly } \\
\text { abnormal return. The number of observations represents monthly bidder excess returns over the event windows. } \\
\text { Panel A shows the calculations for the full study period. Panel B presents the results up to January } 2007 \text { (pre- } \\
\text { crisis) and Panel C shows results for the post-January } 2007 \text { sub-period. ***, **, * show statistical significance at } \\
\text { the } 1 \%, 5 \% \text { and } 10 \% \text { level respectively. }\end{array}$} \\
\hline
\end{tabular}

